\title{
Digitalization as a Game-Changer: A Study on Swedish Video Game Industry
}

\author{
Mosarrat Farhana and Daniel Swietlicki \\ Linnaeus University
}

\begin{abstract}
The purpose of this study is to extend the understanding of the business model of video game retailers using online and physical stores. It focuses on the impact of digitalization on the retailing industry considering different actors like retailers and consumers. This is a qualitative multiple-case study based on deductive reasoning. Two cases of click-and-mortar retailers operating in the Swedish video game industry have been considered along with feedback from customers. Online personal interviews and semi-structured interviews have been conducted with retailers and customers respectively. Both primary and secondary data have been used. Findings show that video game retailers need to encourage engagement through incentives and other activities to create value and change up their formats and sales strategies through pricing to reach new customers and focus on design of their online store fronts to convey trustworthiness. It offers some insightful practical suggestions to retailers who are struggling hard to adopt digital transformations in the industry. Authors' proposed research model, based on Sorescu et al. (2011)'s retail business model and the empirical findings, contributes in the less explored domain of research on business models from retailer's perspectives. Moreover, it adds values in industry specific study like the video game industry in Sweden considering all actors, which is argued as scarce.
\end{abstract}

\section{Introduction}

The exponential growth of the business-to-consumer (B2C) e-commerce activities in the world marketplace has brought revolutionary transformation in retailing and grown dramatically since 1997 (Otto and Chung 2000; Doong et al. 2010). According to Statista, in 2018 approximately 1.8 billion people worldwide purchased goods online from brick-and-mortar retailers like Walmart as well as from web-only retailers like Amazon or Rakuten and in 2021 the figure is expected to be over 2.14 billion (Clement 2019). Based on organization's e-commerce activities, researchers have defined three types of organizations like (1) completely physical companies - 'brickand-mortar', (2) companies using some e-commerce activities as marketing channels - 'click-and-mortar', and (3) companies only based on e-commerce activities - 'virtual organizations' (Turban et al. 2009; Doong et al. 2010). The retail industry has witnessed disruptive changes every 50 years or so, due to ongoing technological advancement and societal changes (Rigby 2011). The emergence of digitalization of retailing along with omnichannel concept has transformed consumer's shopping behavior and expectation in favor of the digital platform of brick-and-mortar retailers (Betzing et al. 2018). History shows that over time each wave of change did not abandon the earlier format, rather it has reshaped the landscapes of the retail industry by adopting new changes in the old format and redefined consumer's expectations (Rigby 2011). Retailing as a core function of all economies will not be extinct in the near future, but traditional brick-and-mortar physical retailers will endanger their existence without adopting the concept of digital retailing in their business model (Rigby 2011; Reinartz et al. 2019). Since virtual organizations are enjoying some crucial operational benefits such as reduced cost, 24/7 open store, less communication cost, geographical barriers and so on, a growing number of brick-and-mortar companies have turned into click-and-mortar ones (Otto and Chung 2000; Steinfield et al. 2002; Doong et al. 2010). Moreover, as an inevitable part of the e-commerce platform companies can offer consumers more personalized services based on personal data and can also design tailored advertisements to reach the target audience (Rigby 2011; Piotrowicz and Cuthbertson 2014; Zhu et al. 2017; Reinartz et al. 2019;).

To combat the fierce competition, brick-and-mortar retailers have integrated different in-store digital technologies like self-service terminals, in-store assistant, mobile payment, virtual mirrors, QR codes and so on to uplift consumer's shopping experience through multiple channels (Piotrowicz and Cuthbertson 2014; Betzing et al. 2018). But the pervasive advancement and deployment of new technologies like different smart devices and social network across the retailing landscape have blurred not only the line between online and physical retailers, but also the boundaries between retailers and manufacturers (Brynjolfsson et al. 2013; Piotrowicz and Cuthbertson 2014; Reinartz et al. 2019). Therefore, the omnichannel concept has evolved substituting existing multiple channels, with an aim to deliver a seamless, unified customer experience (Piotrowicz and Cuthbertson 2014; Reinartz et al. 2019). This digital transformation affects the retailing arena to a great extent, as manufacturers have entered that interface to engage directly with the end consumer instead of the traditional retailer (Reinartz et al.

(C) 2021 Author/s. This is an Open Access article distributed under the terms of the Creative Commons Attribution-

NonCommercial 4.o International License (http://creativecommons.org/ licenses/by-nc/4.o/), permitting all non-commercial use, distribution, and reproduction in any medium, provided the original work is properly cited.

https://doi.org/10.15626/lscit2020.01

ISBN: $978-91-89283-51-0$ 
2019). This is the case for the video game industry, as publishers and developers are now directly connected with consumers and have their own online stores such as Origin, Microsoft store and PlayStation store (Polo 2019).

The video game industry is an industry that has been on the rise for the past 20 years (Jöckel et al. 2008; Waldner et al. 2013; Johnson and Woodcock 2019), by reaching a worth of 151,9 billion dollars in 2019 from 76,5 billion dollars in 2013 (Wijman 2019). With this steady growth the industry is catching up and has even passed the film industry in 2018 that had a global box office revenue of 41,1 billion dollars (Statista 2019a). This trend is expected to continue with a CAGR (Compound Average Growth Rate) of 9\% till 2022 as consumers continue to play and newer platforms like mobile and tablets gain popularity among gamers (Wijman 2019). Due to new technology, the industry has changed over the years in terms of better-quality games and new distribution channels (Waldner et al. 2013; Davidovici-Nora 2014). A video game itself can be described as "a game played by electronically manipulating images produced by a computer program on a monitor or other display". Video games are often made for platforms such as PC (personal computer), dedicated consoles like Xbox, PlayStation and Nintendo Switch playing on a TV and mobile phones (Wijman 2019). Video games have traditionally been sold in retail stores such as GameStop, MediaMarkt and Walmart but gradually digital retailers such as Steam, Origin, Microsoft store and PlayStation store have nearly taken over the physical sales of video games (Polo 2019). Following the American market, in 2018 83\% of all video games sold were in digital form which was a dramatic change since a decade earlier $80 \%$ of all sales were physical (CD, DVD, SD card or cartridge) (Statista 2019b). However, sales of physical console games are still owning around 66\% of the market worldwide in 2017 (Wepc 2020). But this number is getting smaller each year as retailers are adapting to new ways of distribution. The physical retailer GameStop in their annual 10k report has focused on the growing trend of downloading games and expressed concern about losing consumers due to their changing purchase behavior (GameStop SEC 10-K form 2019). Many industry experts and researchers have predicted that the basic role of the retailer or middlemen has shrunk enough to be questionable in the near future (Otto and Chung 2000; Rigby 2011; Piotrowicz and Cuthbertson 2014; Reinartz et al. 2019). For survival it is obvious for any organization to embrace the emerging concept of digital platform (Kumar 2018; Varadarjan 2018; Reinartz et al. 2019). In the last few years, the digital distribution platform has brought disruptive shifts into the video game industry (Davidovici-Nora 2014) and has challenged the existence of the physical retailer in the coming years (HBS Digital initiative 2017). The declining phase of the big brick-and-mortar video game retailer - GameStop has revealed the changing dimensions in this industry and raised questions about the position of retailers and middlemen in future (HBS Digital initiative 2017; Gilbert 2020). Different research works reveal that due to technology, this industry is going through radically changing distribution channels like the music industry; where the boundaries between consumer and developers have become more permeable than before (Potts et al. 2008; Jöckel et al. 2008; Waldner et al. 2013; Payne 2018).

Different scholarly works within the field of e-commerce have focused on the immense impact of digital platforms on existing retailing industry and consumers, but industry specific empirical study on the retailing business model embracing technological advancement is found to be less explored. Existing research have mostly emphasized the marketing strategy and value co-creation process in the video game industry from only developers' perspectives. Though the video game industry has been defined as one of the fastest growing industries worldwide by the academic researchers and industry experts (Johnson and Woodcock 2019; Teipen 2008), it has received little scholarly attention from the arena of business and economics (Zackariasson and Wilson 2012) specifically in European region (Nieborg and de Kloet 2016). A few research works have highlighted the vulnerable position of the physical retailers in the industry (Payne 2018) and have considered the growing radical innovations and the highest number of internet-enabled households in certain countries like the Netherlands, Norway, Sweden, Denmark, Germany, the UK and France as catalysts in this changing business environment (Nieborg and de Kloet 2016). Researchers have further argued that the Northern European countries are in the forefront to adapt to this digital transformation in the existing business models in the industry.

With such notions, this study intends to focus on balancing between online and physical sales and explore the business model of the retailers in the Swedish video game industry considering their future business strategies. This study will also consider consumers' viewpoints to generate a holistic view of existing practice in the industry and its prospects. Since in a retailer's business model value is delivered to customers and appropriated by the retailer and its partners including suppliers (Sorescu et al. 2011), it is crucial to have all actors' viewpoints to define retailer's position in the industry. Thus, this dyadic research encompassing both retailers and consumers will cover how changes in the physical and digital environment influence the business and offer insights and directions to the retailers and middlemen who are facing the first wave of shock. The outcome of this study will contribute to the scholarly field of retailing practice in the era of digitalization. 


\section{Research questions}

- How does e-commerce impact the business model of retailers in the gaming industry?

- Why is the contribution from different actors in a retailer's business model crucial for both the value creation and appropriation processes?

\section{Theoretical Framework}

\section{Business Model and Impact of Digitalization}

Technological advancement and customers' increased access to digital platforms have made firms adopt new business models to create new ways for value creation and appropriation (Gatignon et al. 2017). Statistics show that over the next five years, about $80 \%$ of firms are planning to adopt new business models (Accenture 2014; Gatignon et al. 2017). Since 1995 the concept of business model has been explored by different researchers in more than 1177 peer-reviewed articles (Zott et al. 2011). According to Zott and Amit (2010), business model refers to a system of interdependent activities articulating a firm's value proposition, sources of revenue, its utilized resources to extract rent and the governance which basically connects firm's different stakeholders. Based on this core idea Sorescu et al. (2011) has proposed a working definition as: 'A business model is a well-specified system of interdependent structures, activities, and processes that serves as a firm's organizing logic for value creation (for its customers) and value appropriation (for itself and its partners)' (p. S4). In a recent study Müller et al. (2018) have argued that a business model depicts the ways how organizations conduct different activities to deliver value to the customers and how they interact with suppliers, customers, partners in their network, and finally how they get feedback from customers. In summary, in the widespread recognized literature, most of the researchers have agreed that a business model should be able to connect value creation and capture (CasadesusMasanell and Ricart 2010; Teece 2010; Zott and Amit 2010; Zott et al. 2011; Baden-Fuller and Haefliger 2013; Baden-Fuller and Mangematin 2013).

The pervasive penetration of the internet has created a 'high velocity environment' (Wirtz et al. 2010) with changing customer preferences, which has made modern organizations to adopt e-business models as a way of survival (Phillips and Wright 2009). Historically the success of e-commerce pioneer Dell, Amazon and e-Bay has been attributed to their novel e-business models (Chen 2003). Baden-Fuller and Haefliger (2013) have argued in their study that 'Business models and technologies interact regularly' (p. 419). Researchers have further argued that e-business encompasses e-commerce and beyond by including the implementation of information technologies for internal processes as well as external commercial activities and interactions with suppliers and customers (Phillips 2003; Phillips and Wright 2009). During the early phases of the internet, a good number of business models have been proposed to the management to find the best one for pursuing e-business (Phillips 2003; Phillips and Wright 2008). According to Chen (2003), based on classification, more than 29 e-business models have been discussed by different authors. However, following those studies Mahadevan (2000) and Weill and Vitale (2001) have considered four distinct concepts to define business models for e-business, which are: 1)the supply chain model, 2) the revenue model, 3) whether the model aims B2B or B2C market and 4) whether the firm is pure-play (online) or click-and-mortar. Considering the immense growth of e-commerce Turban et al. (2009) have classified business organizations into three groups such as brick-and-mortar organization or purely physical companies (Doong et al. 2010), click-and-mortar organizations that is integrating e-commerce in physical retail outlets (Adelaar et al. 2003) and virtual or solely e-commerce based online companies (Turban et al. 2009; Doong et al. 2010).

\section{Retail Business Model (RBM)}

Globally, the retail landscape is encountering revolutionary changes due to the boom of the internet era (Sorescu et al. 2011) and have adopted new business models (Gatignon et al. 2017). According to Sorescu et al. (2011) over the years retailers have started to shift their focus from simply selling products towards creating a rewarding customer experience. Most retailers nowadays operate as multichannel firms where the customer can reach the retailers through different channels like online and offline (Sorescu et al. 2011).Considering all these changes, the RBM proposed by Sorescu et al. (2011) is found to be the most acceptable one since it combines value creation and appropriation as a prerequisite to understand a business model (Sorescu et al. 2011; Cao 2014; Gatignon et al. 2017). This RBM (Sorescu et al. 2011) is made of three key components-retailing format, retailing activities and retailing governance. Along with these three elements, Sorescu et al. (2011) also put forward six design themes with its own approach to enhancing value creation and appropriation through innovation. The first three themes revolve around value creation and are customer efficiency, customer effectiveness and customer engagement. For value appropriation they name operational efficiency, operational effectiveness and customer lock-in. The crucial 
fact is that an isolated change to either of these does not constitute as an innovation to the RBM unless it affects other parts of the business model as well (Sorescu et al. 2011).

\section{Core Elements of Retailing Business Model}

- The core element of retailing format refers to the structuring of activities in a coherent way to create a customer experience which is made of elements from the retailing mix like product assortment, pricing, location customer interface to name a few (Levy and Weitz 2008; Sorescu et al. 2011). Retailers' choice of store location or format like physical or online impact customer reach (Sorescu et al. 2011).

- Sorescu et al. (2011) describe retailing activities as "Refers to acquiring, stocking, displaying and exchanging goods and services that fulfill customer experience." (p. 7). The structure of these activities like store design, product mix, pricing, branding and communication depends on the chosen format.

- Sorescu et al. (2011) describe retailing governance as "Refers to the actors involved in creating and delivering customer experiences, as well as the mechanisms (such as contract and incentive systems) that motivate these actors to carry out their roles in fulfilling the customer experience."(p.7). Actors include customers and the retailer's network of actors in the supply chain. While customer's reviews can reshape customer interface, suppliers can react upon customers' changing needs by modifying their assortment to better fulfill the customer experience (Coughlan and Soberman 2005).

\section{Proposed Research Model}

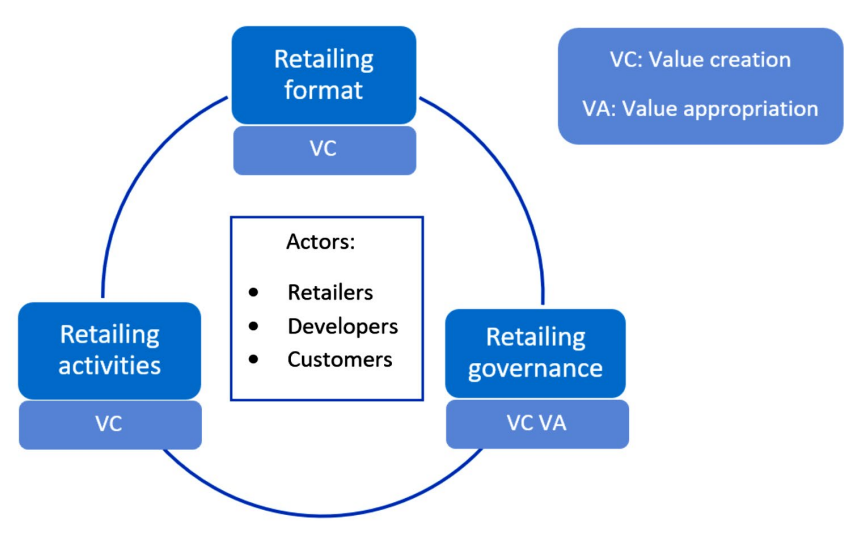

Based on the literature review and the theoretical key concepts, authors have developed the following research model (see Figure 1), inspired by Sorescu et al. (2011)'s proposed retail business model. Here, actors have been defined within the context of the video game industry.

Figure 1: Research model: Adapted from "Innovations in retail business models" by Sorescu et al. (2011)

\section{Assumptions}

Based on the proposed research model (Figure 1) along with theoretical framework, authors present the following assumptions to be tested:

A1: Adopting new technology in retailing format and activities, retailers can ensure enhanced customer value and engagement.

A2: Different actors' contribution in a retailer's governance mechanism due to technological development can create enhanced value for customers, which in turn can help the retailer to maximize value appropriation.

A3: A change in existing one or more elements in the retailing business model (i.e. retailing format, activities and governance) lead to change in other elements resulting in a retail model innovation and generate new options for value creation and appropriation.

\section{Methodology}

\section{Research Design \& Strategy}

This is a qualitative exploratory research based on deductive reasoning, because existing research only highlights the eroding position of physical retailers in the video game industry (Payne 2018) and does not give clear understanding on retailer's business models due to digital transformation of the industry (Baden-Fuller and Mangematin 2013). Therefore, a qualitative approach is the most suitable one in line with the purpose of study. Since the authors intend to find answer of the research questions based on a conceptual framework rooted to 'the retailing business model' by Sorescu et al. (2011), deductive approach is found to be appropriate for its nature of 'theory testing' process rather than building theory from collected data (Carson et al. 2001; Hair et al. 2011). Here exploratory research design has been preferred, as this study is carried out in a technology intensive industry addressing a less explored field to identify new relationships, patterns or themes (Hair et al. 2011). Moreover, a multiple-case study strategy has been followed considering the depth of existing knowledge, time and resources 
to investigate this contemporary phenomenon within the context of a real-world case (Yin and Davis 2007), following the proposed 'how' and 'why' research questions (Yin 2014). This strategy has helped identify similarities or differences between the cases (Eisenhardt 1991; Yin 2014; Bell et al. 2019).

\section{Data Collection Method \& Instruments}

In order to ensure cross-case comparability along with a standardized approach in a multiple-case study, researchers have agreed to use a qualitative interview technique (Bryman et al. 1996) to reflect more on the interviewee's own perspective (Bell et al. 2019). For each case of retailer, authors have conducted online personal interviews (Bell et al. 2019) using a structured interview schedule with a set of predetermined open-ended questions (Hair et al. 2011). Due to the locations of retailers in different cities (e.g. Stockholm, Gothenburg, Karlstad and so on) as well as the outbreak of Coronavirus pandemic, online personal interviews via emails have been preferred over face-to-face interviews. Finally, semi-structured face-to-face interviews have been conducted using an interview guide (Bell et al. 2019) to collect data from the consumers. To ensure social distancing during this pandemic, a few interviews have been conducted via Discord and Skype. Each interview with a duration of approximately 25-30 minutes has been audio recorded and transcribed. Authors have also gathered secondary data from different reliable sources like company websites, industry review reports, articles and so on to enhance the quality of the data analysis process (Bryman and Bell 2015).

\section{Selection of Cases \& Respondents}

Though five retailers have expressed their interests to participate in this study initially, due to COVID-19 pandemic three retailers have refused to participate and only two retailers of click-and-mortar model have contributed to this study. Convenience sampling technique has been followed to reach them within a limited timeframe (Easterby-Smith et al. 2015). Authors have selected retailers operating in Sweden, based on the information available in the Swedish games industry report (Dataspelsbranschen 2019) and the Prisjakt (Prisjakt.se) website selling video games. The ICT related R\&D investment enduring potentials of the video game industry (Beinisch et al. 2005; Nieborg and de Kloet 2016) and more specifically, Sweden's frontrunner position in leading local game development communities (Nieborg and de Kloet 2016), have motivated authors to pursue this study on Swedish retailers.

Since retailers have preferred to be anonymous, they have been named as Retailer Blue for case 1 and Retailer Green for case 2. Retailer Blue has started its operation in 2000 in Göteborg and then it has expanded business in Stockholm and Malmö. It has circa 100 employees and sells physical video games and digital codes, accessories, consoles and game related devices. It has received numerous awards for its operational excellence among which in 2019 it has received 9 awards from the Better Business organization for its outstanding customer service. Retailer Green has started its journey in 1994 as a small-town entrepreneur in Karlstad and now it operates in over 40 countries. It has circa 50-100 employees and sells physical video games, figurines accessories, consoles, game related devices and second-hand copies. Green is working with all major publishers and numerous distributors across the world. In both cases, CEO and Product Managers have been interviewed.

Purposive sampling technique following researchers' own judgment and experience (Hair et al. 2011; Bell et al. 2019) has been employed to reach a group of customers in Sweden, who play video games on different platforms regularly (almost each week); and have adequate knowledge about the industry to give insightful feedback. Sixteen anonymous customers have been interviewed among which two have been discarded due to irrelevant and incomplete information. Authors have decided to stop interviewing after 14th to avoid data redundancy. Respondents are both male and female with almost the same ethnic background that is Swedish, within the age group of 19-45.

\section{Data Analysis Method}

Since this study, rooted to deductive reasoning, aims to focus on individual respondents' perceptions on the research topic, authors have preferred to employ the thematic analysis method to analyze multiple cases (Flick 2014). It has led researchers in identifying some patterned response or meaning across the data set relevant for the research question. Moreover, the flexible nature of the thematic analysis approach has allowed authors to categorize the empirical data and summarize those under some core themes to understand the phenomenon (Bryman and Bell 2015). The authors have employed a coding process manually to identify and interpret some patterns and themes from the empirical data to develop ideas (Hair et al. 2011; Bryman and Bell 2015). 


\section{Quality Criteria}

In this study, data triangulation (Hair et al. 2011) has been used by collecting data from different sources such as primary data from both retailers and customers, and secondary data from published articles and industry reports to have a clear picture of the whole phenomenon. To achieve confirmability of this study, both authors have worked in 'good faith' (Bryman and Bell 2015) by strictly avoiding any kind of personal influence on respondents' feedback. Moreover, after completing fourteen semi-structured interviews, authors could find some patterns among the respondents and this recurring pattern signal the higher quality of the data as well as credibility of the study (Bryman and Bell 2015). Consistency in the coding process is emphasized to ensure reliability aspect (Hair et al. 2011).

\section{Ethical Aspects}

Bell et al. (2019) have suggested business researchers to follow four main ethical principles, which are: 1) avoidance of harm to participants, 2) obtaining informed consent, 3) protection of privacy through confidentiality and 4) preventing deception. In this study authors have strictly followed all these ethical principles while conducting interviews specifically recording and transcribing the conversation and analyzing the data.

\section{Empirical Findings and Analysis}

\section{Assumption 1:}

Both retailers Blue and Green have a click-and-mortar business model. In response to the fierce competition in the industry due to digital distribution, they have adopted new technologies in their retailing format and activities at different levels. They are found to be very specific and optimistic about their market position and customer segments. Pricing strategy with some value-added discounts is found to be a key success factor for both retailers. To differentiate their positions in the market, they have preferred to keep an array of choices for their customers. Among those product assortments, some are next to impossible to be offered by any digital retailers in terms of product experience, such as physical copies of games, added contents or accessories, secondhand copies of old generation games and so on. While retailer Green has emphasized their strong global network of publishers, distributors and retailers to create extra value for customers via retailing format and activities, retailer Blue has preferred to focus more on enhanced in-store customer experience on their virtual space. The product manager of Blue admits that: "One of the major flaws when dedicating to only online sales is the loss of customer interaction in person." To overcome this challenging aspect of the click-and-mortar business model, retailer Blue is keen to utilize modern technology and different social platforms as part of their omnichannel strategy. For example: online competition, podcasts, live streaming on their website and YouTube channel are used to reach the customers directly and create value for them. Moreover, both retailers Blue and Green have always prioritized value-added quick delivery service like pickup at convenient spots, free delivery and return. In this process of value creation, both have mentioned the vital role of technological advancements.

Customers' interviews show that most of them are not interacting much with new technology in the physical stores or are at least not aware of any such innovation in retailing. They have appreciated self-service format of the online stores greatly due to ease of purchase and more value creation by spending less time and money. Using data about customer preferences retailers could reach customers with specific interest via email or direct messages. It has helped retailers to design the assortment and created value for both retailers and customers. However, many customers have expressed their deep concerns about the trustworthiness of the website during purchase.

From this analysis, assumption 1 is found to be true. Retailers have adopted new technologies in their retailing format and activities to engage and interact with their customers, but to some extent customers fail or simply do not bother to recognize their efforts in value creation. Thus, in many cases there is a gap between retailers switching up the format and customers. Moreover, retailers need to be more concerned about the cyber security to ensure more customer engagement.

\section{Assumption 2}

Both retailers have preferred to work in direct collaboration with other actors in the industry such as developers, publishers and customers while planning and designing product assortments in their stores. They have put immense importance on customer feedback, though they could not specify customers' contribution in value 
creation in terms of retailing governance. In that context, retailer Blue has pointed out publishers' contribution in both value creation and value appropriation process by sharing previous data on sale. Both retailers have divided the value appropriation process into two aspects of value: brand and monetary. Due to the booming digital distribution channel, both retailers are operating in low-margin market segments, but with a high volume of sales. In that context, they have emphasized on having a tight tie with all renowned branded publishers to uplift their own brand value in the industry. Blue has stated that balancing between both monetary and brand values out way their costs to move forward. Moreover, Blue has talked about developers' influence on customers by creating hype in the market before releasing any game; which always impacts retailer's business both positively and negatively. Both retailers have found developers, publishers and customers as co-producers in their value appropriation process. More specifically, customers' interest in game related accessories have opened up new opportunities for retailers at the declining phase of physical copies of games. Blue has argued that as incentive driven customer lock-in strategies are not enough to create a sustainable loyal customer base on the online space, they prefer to create value through excellent customer contact and services. While retailer Green has claimed them as a more physically driven company, retailer Blue has acknowledged the role of technology in their operational excellence. However, they have stated that some unavoidable incidents in the shipment process cannot be solved by modern technology.

Most of the customers have admitted that they almost never left any reviews for stores to improve their interface or design. Despite the technological ease of customer review system, many seems to ignore this for trivial reasons. However, they prefer to read other customers' reviews during online purchase. Thus, customers' honest feedback contributes in value creation for customers and help retailers to boost value appropriation. In terms of co-creation respondents have mentioned that adding games to their WishList on online stores inform retailers, developers and publishers about customers' preferred games and allows them to set up a sales plan to gain value from customer demand.

Analyzing both retailers' and customers' feedback, assumption 2 is found to be true. Different actors' contribution is found to be an integral part in both value creation and appropriation in the retailer's business operation, where technology plays the role of a springboard to accelerate the process. Since product price drives most of the customers, retailers need to be more proactive to engage customers on the same platform as the other actors to create unique values. They can also provide an incentive to customers to write honest reviews to create value but should avoid going into bribing territory.

\section{Assumption 3}

According to assumption 1 and assumption 2, both retailers have reshaped their business operations and strategies to some extent by adopting technological transformation in the industry. They have tried to create new options and have applied omnichannel strategies to deliver value as well as to appropriate the value. Expanding business on the digital platform in parallel to the physical outlets has brought changes in retailing format and retailing activities, which in turn has also impacted retailing governance. A single change in retailing format like online store has brought changes in other elements - retailing activities and governance gradually to sync each other's roles. Since both retailers are simply balancing between their physical and digital operations following a clickand-mortar business model rather than completely switching on the digital platform, there is no radical innovation in their business model. Moreover, both have followed industry trends to generate new options to expand the market or to grab a new customer base.

Changes in selling platform and strategy have made retailers bring changes in retailing format which has a chain effect on retailing activities and governance for both value creation and appropriation. The change in format has brought new ways of organizing sales and special offers. Retailers' access to personal data and preferences let them create customized offers and incentives resulting in impulsive purchases by customers generating value for both parties. This chain effect of changes on those three elements of the RBM have created different opportunities for retailers to reach customers following new strategies and channels but have not brought any drastic change in their business model to claim an innovation in the RBM. Therefore, assumption 3 is found to be partially true.

\section{Corroborating Themes}

After carefully reviewing and analyzing all gathered data, authors have extracted codes and have connected different sets of codes based on three theory driven thematic nodes naming Retailing format, Retailing activities and Retailing governance. To conduct this thematic analysis, authors have focused on similarities and differences between different clusters of data relating the research question, to figure out any potential conflict. Following the 
key concept and the proposed research model, data under each thematic node has been framed. Here, the concepts of value creation and value appropriation in the retailing business model have worked as key drivers. After this initial phase, authors have further analyzed different sets of coded data extracts to combine most relevant ones and to form an overarching theme. Therefore, a set of clustered themes have been developed narrowing down to three core themes reflecting on the phenomenon; which are presented in the following Table 1:

\begin{tabular}{|c|c|}
\hline Clustered themes & Core themes \\
\hline $\begin{array}{l}\text { - Transformation of format to digital platforms leads to use of omnichannel } \\
\text { strategy to reach a wider range of customers via effective communication. } \\
\text { - Value driven incentives and pricing strategy are crucial to motivate } \\
\text { consumers to buy a physical game over a digital one and retain them. } \\
\text { - Replicating the physical store atmosphere on the online store is vital for } \\
\text { click-and-mortar retailers to enhance customer engagement in the value } \\
\text { creation process. } \\
\text { - Incentives to contribute to the value creation with reviews is important } \\
\text { for managing trustworthiness and perception of cyber security. } \\
\text { - Strong network of different actors along with their brand value } \\
\text { contributes to value appropriation such as profit maximization \& excellence } \\
\text { in the supply chain. }\end{array}$ & $\begin{array}{l}\text { - Well communicated pricing } \\
\text { strategy and value driven } \\
\text { incentives } \\
\text { - Encourage customer } \\
\text { engagement and reviews via } \\
\text { activities and interaction on } \\
\text { online platform } \\
\text { - Trustworthy and secured } \\
\text { digital platform connecting all } \\
\text { actors }\end{array}$ \\
\hline
\end{tabular}

Table 1: Corroborating Themes

In summary, after analyzing results from both retailers and customers' perspective, for success retailers need to have planned pricing strategies and have value driven incentives and be able to communicate these to their customers. To create value for both retailers and customers they need to find ways to engage customers and encourage them to interact more and leave reviews for others. This helps with conveying the reliability of the store or website that can be effective platforms for other actors to gather and contribute in both value creation and appropriation.

\section{Discussion}

\section{Changing Landscape of Retailing}

Both retailers have further explained that industry trends and consumer preferences have reshaped their business operations and inspired them to adopt e-business models as argued by Phillips and Wright (2008). Specifically, the brick-and-mortar retailers (Enders and Jelassi 2000; Phillips and Wright 2008; Piotrowicz and Cuthbertson 2014; Reinartz et al. 2019;) have almost been phased out and the click-and-mortar retailers are struggling to combat the competition by the online retailers. Now, a question might arise: why they are still following the clickand-mortar business model (Adelaar et al. 2003) rather than the online (Turban et al. 2009; Doong et al. 2010) one. In that context, the case of retailer Blue and a few number of customer feedback have pointed out that the missing aspects of customer contact in person and customer's emotion across 'touch, feel and try' the product perspective (Enders and Jelassi 2000; Adelaar et al. 2003) on the online store work as drivers for retailers to follow the click-and-mortar model. Moreover, the 'nostalgia' motivates some customers to be in a physical store, browse products and make impulsive purchase decisions. The increasing popularity of retro and vintage physical games and consoles is also a factor for companies to still operate with physical stores.

\section{Retailer's Business Model}

Both retailers have embraced e-commerce (Baden-Fuller and Haefliger 2013) to create new options for value creation and capture (Casadesus-Masanell and Ricart 2010; Teece 2010; Zott et al. 2011; Baden-Fuller and Haefliger 2013; Baden-Fuller and Mangematin 2013; Ruggieri et al. 2018) in collaboration with different stakeholders (Zott and Amit 2010; Sorescu et al. 2011; Müller et al. 2018). Since different actors like customers, retailers, developers and publishers are well connected via digital platform, theoretically these two retailers' way of business operation more fits into Sorescu et al. (2011)'s proposed RBM. To enhance customer experience and engagement, retailer Blue implements omnichannel strategies through channel integrations as suggested by researchers (Steinfield 2002; Cao 2014; Piotrowicz and Cuthbertson 2014). But from consumer perspectives, lack of well-coordinated communication between customers and retailers and credibility issue on online platforms have made consumers less motivated to be engaged (Farhana and Swietlicki forthcoming). Both retailers reflect on the 
importance of technology to integrate different actors in creating value and maximizing profit and brand value via value appropriation process (Sorescu et al. 2011; Müller et al. 2018).

\section{Future of the Industry}

They all agree that digitalization is affecting the future lifespan of physical copies, as digital purchase of games is going to increase with the evolution of consoles promoting their own digital marketplaces and game streaming services (Waldner et al. 2013; Morris 2018). Retailers are still optimistic about the future of physical copies but realize that they too must adapt to trends and new ways of distribution of games (Toivonen and Sotamaa 2010;

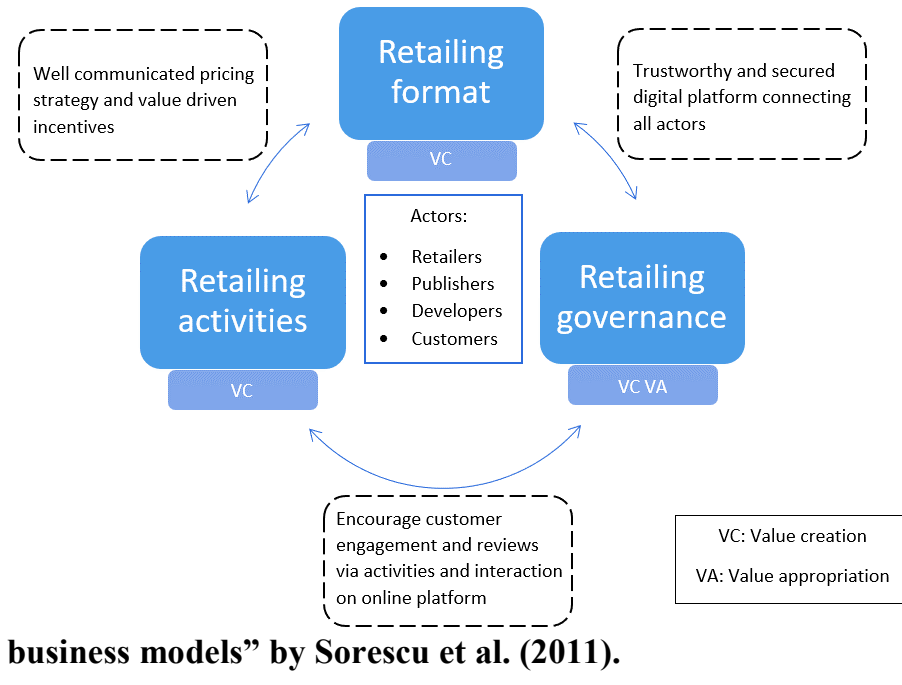
Morris 2018). Respondents are becoming more used to downloading digital copies and ordering online indicating extinction of physical copies eventually as film and music industries went through.

Considering the empirical findings, authors have proposed a revised research model (see Figure 2) to have a comprehensive view of this ongoing phenomenon relating to the research questions. This model can be used for further theoretical and empirical research.

Figure 2: Modified research model: Adapted from "Innovations in retail

\section{Conclusions and Contributions}

Since change in one element of the retail business model impacts other elements to adopt some changes, all elements need to be synced. Moreover, different actors in the industry ecosystem play significant roles in each element of the RBM (Sorescu et al. 2011) to create and capture value in collaboration with the retailer. Following this model, retailers need to act on the ongoing shift in the video game industry to keep pace with other actors. If video game publishers, developers and customers completely upgrade their state in accordance to the digital transformation of the industry, retailers would need to adopt this transformation in their business model to make those actors contribute to their operation. Otherwise, click-and-mortar retailers will gradually be phased out of the industry ecosystem. According to researchers (Zott and Amit 2010; Sorescu et al. 2011; Zott et al. 2011; Ruggieri et al. 2018) it is revealed that value creation and appropriation are core concepts of a business model, where from the retailers' perspective retailers need to engage other actors to make it viable in the near future. The contributions from different actors like publishers, developers and consumers is of utmost importance for retailers as it affects product assortment, sales activities, formats and more. Customers' contributions with reviews create value for the retailer and other customers, while contributions from publishers and developers with incentives and special offers can attract customers to the stores (Farhana and Swietlicki forthcoming). Practical findings from this study can help retailers engage actors by taking a few steps, such as ensuring a credible digital platform with better incentive strategy in product offerings and review process. Moreover, a better communication strategy can accelerate retailers' existing omnichannel marketing approach.

The sales of physical games are on the wane in comparison to wide options for playing video games on different platforms. But the segment specific market position of click-and-mortar retailers selling physical copies is still promising as uttered by both retailers. Digital platforms such as Steam which are middlemen for developers and customers providing a space to make business are important but make some consumers worried about the future consequences such as losing all games if the service gets shut down. In that context, click-and-mortar retailers can expand their digital operations by capitalizing on the brand value of their physical store. They need to balance between physical and online operations to face the future challenges.

Though the nature of qualitative study does not allow researchers to formulate a generalized understanding, the findings of this study contribute in academic and practitioner-oriented interdisciplinary research fields. Theoretically it contributes in less explored field of retail business model and industry specific study, focusing the phenomenon of digitalization. A number of managerial implications come from the learning on these Swedish 
retailers at verge of industry transformation and these are: adapting arcade café concept to retain customers via gamers' physical community platform, integrated communication strategy leveraging omnichannel concept and competitive pricing strategy.

\section{Limitations and Further Research}

While collecting data for this study, the authors have encountered an unforeseen problem due to COVID-19 pandemic, which has affected the authors' ability to collect data from both retailers and customers. To overcome this challenging situation, different techniques have been used to ensure spontaneity of the interviews. Furthermore, legal contract with the parent company or the big publisher has worked as a root cause for several retailers refraining from this study despite of non-disclosure agreement option. It has simply limited this study to be more extensive.

This qualitative research can work as a foundation to conduct further research in this industry following two probable ways such as:

1. A longitudinal case study on two specific types of retailers that is click-and-mortar and online over a lengthy period to investigate how retailers are reshaping their business model gradually in response to the industry transformation.

2. Another option could be a quantitative study to measure interdependencies of three elements - retailing format, activities and governance in the revised research model and to test their effects on customer experience and retailer's performance.

\section{References}

Adelaar, T., Chang, S., Lancendorfer, K.M., Lee, B. and Morimoto, M. 2003. Effects of media formats on emotions and impulse buying intent. Journal of Information Technology 18(4), pp. 247-266.

Accenture. 2014. Remaking customer markets: Unlocking growth with digital, Accenture Report. Available at: https://www.accenture.com/t20150715t045909_w_/us-en/_acnmedia/accenture/conversionassets/dotcom/documents/global/pdf/strategy_4/accenture-remaking-customer-markets-unlocking-growthdigital.pdf [Accessed: 28 February 2020].

Amit, R. and Zott, C. 2001. Value creation in e-business. Strategic Management Journal 22(6-7), pp. 493-520. https://doi.org/10.1002/smj.187

Baden-Fuller, C. and Haefliger, S. 2013. Business models and technological innovation. Long Range Planning 46(6), pp.419-426. https://doi.org/10.1016/j.lrp.2013.08.023

Baden-Fuller, C. and Mangematin, V. 2013. Business models: A challenging agenda. Strategic Organization 11(4), pp. 418-427. https://doi.org/10.1177/1476127013510112

Betzing, J.H., Hoang, A.Q.M. and Becker, J. 2018. In-store technologies in the retail servicescape. In: Proceedings of the Multikonferenz Wirtschaftsinformatik. Lüneburg, 06-09 March, 2018. pp. 1671-1682.

Beinisch, Y., Paunov, C., Vickery, G. and Wunsch, V. 2005. Digital broadband content: The online computer and video game industry. Paris: OECD.

Bell, E., Bryman, A. and Harley, B. 2019. Business research methods. $5^{\text {th }}$ ed. Oxford: Oxford University Press.

Brynjolfsson, E., Hu, Y. J. and Rahman, M. S. 2013. Competing in the age of omni-channel retailing. MIT Sloan Management Review, 54(4), pp. 23-29.

Bryman, A. and Bell, E. 2015. Business research method. UK: Oxford University.

Bryman, A., Stephens, M. and Campo, C. 1996. The importance of context: Qualitative research and the study of leadership. The Leadership Quarterly 7(3), pp. 353-370. https://doi.org/10.1016/S1048-9843(96)90025-9

Casadesus-Masanell, R. and Ricart, J. 2010. From strategy to business models and on to tactics. Long Range Planning 43, pp. 195-215. https://doi.org/10.1016/j.lrp.2010.01.004

Cao, L. 2014. Business model transformation in moving to a cross-channel retail strategy: A case study. International Journal of Electronic Commerce 18(4), pp. 69-96. https://doi.org/10.2753/JEC1086$\underline{4415180403}$

Carson, D., Gilmore, A., Perry, C. and Gronhaug, K. 2001. Qualitative marketing research. London: Sage.

Clement, J. 2019. Digital buyers worldwide 2021. Available at: https://www.statista.com/statistics/251666/number-of-digital-buyers-worldwide/ [ Accessed: 3 February 2020].

Chen, S. 2003. The real value of 'e-business models. Business Horizons 46(6), pp.27-33. 
Coughlan, A. T. and Soberman, D.A. 2005. Strategic Segmentation using Outlet Malls. International Journal of Research in Marketing 22(1), pp. 61-86. https://doi.org/10.1016/j.ijresmar.2004.03.003

Dataspelsbranschen. $\quad$ (2019). Spelutvecklarindex $2019 . \quad$ Available at: https:/static1.squarespace.com/static/5a61edb7a803bb7a65252b2d/t/5db6be7415366869893e1866/1572257 420429/Spelutvecklarindex2019_v3.pdf [Accessed: 15 February 2020].

Doong, H.S., Wang, H.C. and Foxall, G.R. 2011. An investigation of consumers' webstore shopping: A view of click-and-mortar company. International Journal of Information Management 31(3), pp. 210-216. https://doi.org/10.1016/j.ijinfomgt.2010.06.006

Davidovici-Nora, M. 2014. Paid and free digital business models innovations in the video game industry. Digiworld Economic Journal 94, p. 83.

Enders, A. and Jelassi, T. 2000. The converging business models of Internet and bricks-and-mortar retailers. European Management Journal 18(5), pp. 542-550. https://doi.org/10.1016/S0263-2373(00)00043-8

Eisenhardt, K.M. 1991. Better stories and better constructs: The case for rigor and comparative logic. Academy of Management Review 16(3), pp. 620-627. https://doi.org/10.5465/amr.1991.4279496

Easterby-Smith, M., Thorpe, R. and Jackson, P.R. 2015. Management and business research. UK: Sage.

Farhana, M. and Swietlicki, D. Forthcoming. Global responsiveness through online and offline value adding. In: Pehrsson, A. eds. Competitive international strategy: Key implementation issues. London and New York: Routledge, pp. 148-156.

Flick, U. 2014. An introduction to qualitative research. UK: Sage.

Gilbert, B. 2020. The world's biggest video game retailer, GameStop, is dying: Here's what led to the retail giant's slow demise. Available at: https:/www.businessinsider.com/gamestop-worlds-biggest-video-game-retailerdecline-explained-2019-7?r=US\&IR=T [ Accessed: 3 February 2020].

GameStop. 2019. SEC filing, GameStop corp. Available at:http://news.gamestop.com/node/16756/html\#s113180BDFBF0C430A7EC3F888A41105B [ Accessed: 3 February 2020].

Gatignon, H., Lecocq, X., Pauwels, K. and Sorescu, A. 2017. A marketing perspective on business models. $A M S$ Review 7(3), pp. 85-89. https://doi.org/10.1007/s13162-017-0108-5

HBS Digital initiative. 2017. Disruption of video game retailers. Available at: https://digital.hbs.edu/platformrctom/submission/disruption-of-video-game-retailers/\# [Accessed: 29 January 2020].

Hair, J., Wolfinbarger, M., Money, A., Samouel, P. and Page, M. 2011. Essentials of business research methods. New York: M.E. Sharpe.

Jöckel, S., Will, A. and Schwarzer, F. 2008. Participatory media culture and digital online distributionReconfiguring the value chain in the computer game industry. The International Journal on Media Management 10(3), pp. 102-111. https://doi.org/10.1080/14241270802262419

Johnson, M.R. and Woodcock, J. 2019. The impacts of live streaming and twitch. tv on the video game industry. Media, Culture \& Society 41(5), pp. 670-688. https://doi.org/10.1177/0163443718818363

Kumar, V. 2018. Transformative marketing: The next 20 years. Journal of Marketing 82(4), pp.1-12. https://doi.org/10.1509/jm.82.41

Levy, M. and Weitz, B. 2008. Retailing management. 7th ed. Irwin: McGraw-Hill.

Mahadevan, B. 2000. Business models for internet-based e-commerce: An anatomy. California Management Review 42(4), pp. 55-69.

Morris, C. 2018. Evolution of a channel: Gaming retail. Available at: https://www.twice.com/retailing/evolutionchannel-gaming-retail [Accessed: 25 April 2020].

Müller, J. M., Buliga, O. and Voigt, K. I. 2018. Fortune favors the prepared: How SMEs approach business model innovations in Industry 4.0. Technological Forecasting and Social Change 132, pp. 2-17. https://doi.org/10.1016/j.techfore.2017.12.019

Nieborg, D.B. and de Kloet, J. 2016. A Patchwork of potential: A survey of the European game industry. In: Fung, A. eds. Global Game Industries and Cultural Policy. London: Palgrave Macmillan, pp. 201-226.

Otto, J.R. and Chung, Q.B. 2000. A framework for cyber-enhanced retailing: Integrating e-commerce retailing with brick-and-mortar retailing. Electronic Markets 10(3), pp. 185-191.

Payne, M.T. 2018. The long tale of downloadable convergence. Velvet Light Trap 81, pp.70-74.

Phillips, P.A. and Wright, C. 2009. E-business's impact on organizational flexibility. Journal of Business Research, 62 (11), pp. 1071-1080. https://doi.org/10.1016/j.jbusres.2008.09.014

Phillips P. A. 2003. E-business strategy: text and cases. Maidenhead, England: McGraw-Hill. 
Piotrowicz, W. and Cuthbertson, R. 2014. Introduction to the special issue information technology in retail: Toward omnichannel retailing. International Journal of Electronic Commerce 18(4), pp. 5-16. https://doi.org/10.2753/JEC1086-4415180400

Polo, J. 2019. Cloud gaming will determine the new lord of digital distribution. Available at: https://venturebeat.com/2019/02/27/cloud-gaming-will-determine-the-new-lord-of-digital-distribution/ [ Accessed: 3 February 2020].

Potts, J., Hartley, J., Banks, J., Burgess, J., Cobcroft, R., Cunningham, S. and Montgomery, L. 2008. Consumer co-creation and situated creativity. Industry and Innovation 15(5), pp. 459-474. https://doi.org/10.1080/13662710802373783

Rigby, D. 2011. The future of shopping. Harvard Business Review 89(12), pp. 65-76.

Reinartz, W., Wiegand, N. and Imschloss, M. 2019. The impact of digital transformation on the retailing value chain. International Journal of Research in Marketing 36(3), pp. 350-366. https://doi.org/10.1016/j.ijresmar.2018.12.002

Ruggieri, R., Savastano, M., Scalingi, A., D’Ascenzo, F. and Bala, D. 2018. The impact of digital platforms on business models: An empirical investigation on innovative start-ups. Management and Marketing 13(4), pp. 1210-1225. https://doi.org/10.2478/mmcks-2018-0032

Saunders, M., Lewis, P. and Thornhill, A. 2009. Research method for business students. 5th ed. Harlow: Pearson Education Limited.

Sorescu, A., Frambach, R.T., Singh, J., Rangaswamy, A. and Bridges, C. 2011. Innovations in retail business models. Journal of Retailing 87, pp. S3-S16. https://doi.org/10.1016/j.jretai.2011.04.005

Statista. 2019a. Global box office revenue from 2014 to 2018, by format. Available at: https://www.statista.com/statistics/259987/global-box-office-revenue/ [Accessed: 3 February 2020].

Statista. 2019b. Breakdown of US computer and video game sales from 2009 to 2017, by delivery format. Available at: www.statista.com/statistics/190225/digital-and-physical-game-sales-in-the-us-since-2009/ [ Accessed: 3 February 2020].

Steinfield, C., Bouwman, H. and Adelaar, T. 2002. The dynamics of click-and-mortar electronic commerce: Opportunities and management strategies. International Journal of Electronic Commerce 7(1), pp. 93-119. https://doi.org/10.1080/10864415.2002.11044254

Teipen, C. 2008. Work and employment in creative industries: the video games industry in Germany, Sweden and Poland. Economic and Industrial Democracy 29(3), pp. 309-35. https://doi.org/10.1177/0143831X08092459

Teece, D.J. 2010. Business models, business strategy, and innovation. Long Range Planning 43, pp. 172-194. https://doi.org/10.1016/j.lrp.2009.07.003

Toivonen, S. and Sotamaa, O. 2010. Digital distribution of games: The players' perspective. In: Proceedings of the International Academic Conference on the Future of Game Design and Technology. Vancouver, 06-07 May, 2010. pp. 199-206.

Turban, E., King, D., Lee, J., Liang, T. P. and Turban, D. C. 2009. Electronic commerce 2010: A managerial perspective. New Jersey: Prentice Hall.

Varadarajan, R. 2018. A commentary on "transformative marketing: The next 20 years". Journal of Marketing 82(4), p. 15. https://doi.org/10.1509/jm.82.43

Wepc. 2020. 2020 videogame industry statistics, trends \& data. Available at: https://www.wepc.com/news/videogame-statistics/ [ Accessed: 3 February 2020].

Wirtz, B.W., Schilke, O. and Ullrich, S. 2010. Strategic development of business models: Implications of the Web 2.0 for creating value on the internet. Long Range Planning 43(2-3), pp. 272-290. https://doi.org/10.1016/j.lrp.2010.01.005

Waldner, F., Zsifkovits, M. and Heidenberger, K. 2013. Are service-based business models of the video game industry blueprints for the music industry?. International Journal of Services, Economics and Management 5(1-2), pp. 5-20. https://doi.org/10.1504/IJSEM.2013.051862

Wijman, T. 2019. Global games market report 2019. Available at:

https://newzoo.com/insights/articles/the-global-games-market-will-generate-152-1-billion-in-2019-as-the-u-sovertakes-china-as-the-biggest-market/ [ Accessed: 3 February 2020].

Weill, P. and Vitale, M. R. 2001. Place to space: Migrating to eBusiness models. Boston: Harvard Business School Press.

Yin, R.K. 2014. Case study research: Design and methods (applied social research methods). Thousand Oaks, CA: Sage Publications.

Zackariasson, P. and Wilson, T.L. 2012. The video game industry: Formation, present state, and future. UK: Routledge. 
Zhu, H., Ou, C.X., van den Heuvel, W.J.A. and Liu, H. 2017. Privacy calculus and its utility for personalization services in e-commerce: An analysis of consumer decision-making. Information \& Management 54(4), pp. 427-437. https://doi.org/10.1016/j.im.2016.10.001

Zott, C., Amit, R. and Massa, L. 2011. The business model: Recent developments and future research. Journal of Management 37(4), pp. 1019-1042. https://doi.org/10.1177/0149206311406265

Zott, C. and Amit, R. 2010. Business model design: An activity system perspective. Long Range Planning 43(23), pp. 216-226. https://doi.org/10.1016/j.1rp.2009.07.004 